\title{
Extradural, retro-orbital, arteriovenous malformation as the cause of a long-term history of syncope
}

\author{
Gian Piero Carboni, ${ }^{1}$ Carlo Cosimo Quattrocchi ${ }^{2}$ \\ ${ }^{1}$ Department of Nuclear Cardiology, Università Campus Bio-Medico, Rome, Italy \\ ${ }^{2}$ Department of Radiology, Università Campus Bio-Medico, Rome, Italy
}

Correspondence to Professor Gian Piero Carboni, g.carboni@unicampus.it

\section{DESCRIPTION}

In May 2012, a 73-year-old man presented to us with a long-term history of syncope occurring during daily activities, characterised by a rapid onset and spontaneous recovery. He had a history of hypertension and previous coronary stent placement. Technetium-99m sestamibi cardiac scintigraphy and neurological and vestibular assessments were all negative. A head-up tilt test (HTT) and cerebral MRI were then performed. During the HTT, his HR, blood pressure (BP) and cardiac output (CO, $1 / \mathrm{min}$ ) were measured using a Finometer (Finapres, The Netherlands). ${ }^{1}$ When the patient was tilted to $60^{\circ}$ for 20 min without giving any medication, his CO decreased (3.2 vs $4.8 \mathrm{l} / \mathrm{min}$ ), but his $\mathrm{HR}$ (59 vs $62 \mathrm{bpm}$ ) and BP $(122 / 74$ vs $116 / 63 \mathrm{~mm} \mathrm{Hg})$ did not. After sublingual administration of nitroglycerin $0.3 \mathrm{mg}$, the tilting was interrupted because of nausea, blurred vision and dizziness with a minimal further $\mathrm{CO}$ reduction and decrease in $\mathrm{BP}$ to $62 / 43 \mathrm{~mm} \mathrm{Hg}$. A brain MRI revealed the presence of a left retro-orbital, extradural, high-flow arterio-venous malformation (AVM). ${ }^{2}$

In $\mathrm{AVMs}$, the arteries connect directly to veins without a capillary bed in between. This creates a high-pressure shunt. AVMs thus 'steal' blood from the surrounding brain normal tissue (figure 1). This condition of cerebral hypo-perfusion may abruptly worsen and cause syncope in the presence of severe hypotension, which may occur after a HTT or when recovering from some exercise activities. In this patient, AVM treatment options, such as microsurgery, endovascular therapy and radiosurgery, ${ }^{3}$ should be considered.

Learning points

- Extradural retro-orbital arterio-venous malformation is a rare congenital developmental vascular lesion.

- This anomaly may cause haemorrhagic stroke, epilepsy, chronic headache or focal neurological deficits.

- The substantial differences between surgical, endovascular, radiosurgical and multimodality treatments are impacted by age and haemorrhage status.

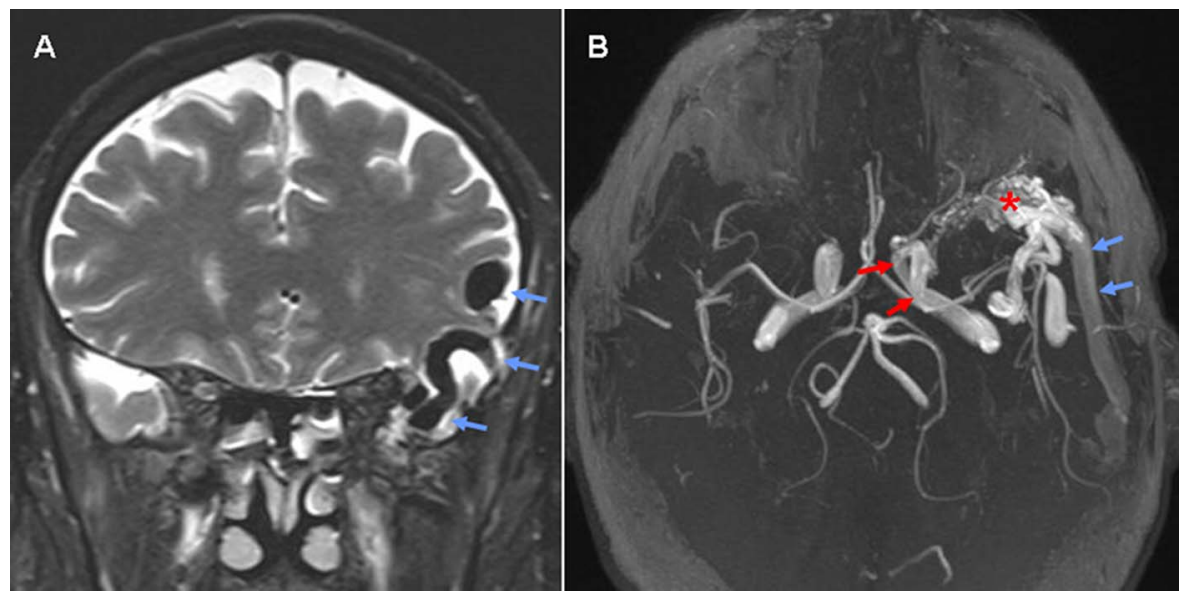

Figure 1 Cerebral MRI. Left retro-orbital, high-flow arterio-venous malformation. (A) Coronal, T2-weighted images show a signal void (blue arrows in A and B) in a vein located in the middle cranial fossa adjacent to the left fronto-temporal lobe. (B) Three-dimensional time of flight-MR angiography images show a central nidus (red asterisk) located posterior to the left orbit that determines a shunt between a small feeding artery originating from the left carotid artery at the level of the cavernous sinus tract (red arrows in B) and the superficial venous drainage. 


\section{BMJ Case Reports}

\section{Competing interests None.}

Patient consent Obtained.

\section{REFERENCES}

1. Bartoletti A, Alboni P, Ammirati F, et al. 'The Italian protocol': a simplified head-up tilt testing potentiated with oral nitroglycerin to assess patients with unexplained syncope. Europace 2000;2:339-42.
2. Laakso A, Hernesniemi J. Arteriovenous malformations: epidemiology and clinical presentation. Neurosurg Clin N Am 2012;23:1-6.

3. Davies JM, Yanamadala V, Lawton MT. Comparative effectiveness of treatments for cerebral arteriovenous malformations: trends in nationwide outcomes from 2000 to 2009. Surg Focus 2012;33:E11.

Copyright 2012 BMJ Publishing Group. All rights reserved. For permission to reuse any of this content visit http://group.bmj.com/group/rights-licensing/permissions.

BMJ Case Report Fellows may re-use this article for personal use and teaching without any further permission.

Please cite this article as follows (you will need to access the article online to obtain the date of publication).

Carboni GP, Quattrocchi CC. Extradural, retro-orbital, arteriovenous malformation as the cause of a long-term history of syncope. BMJ Case Reports 2012;10.1136/bcr-2012-007451, Published XXX

Become a Fellow of BMJ Case Reports today and you can:

- Submit as many cases as you like

- Enjoy fast sympathetic peer review and rapid publication of accepted articles

- Access all the published articles

- Re-use any of the published material for personal use and teaching without further permission

For information on Institutional Fellowships contact consortiasales@bmjgroup.com

Visit casereports.bmj.com for more articles like this and to become a Fellow 